\title{
Transient osteoporosis of pregnancy: case report
}

\author{
Gebelikte geçici osteoporoz: Vaka sunumu
}

\author{
Tolga Ergin ${ }^{1}$, Belgin Selam ${ }^{1}$, Arda Lembet ${ }^{1}$, Harika Bodur Öztürk ${ }^{1}$, Atilla Damlacık ${ }^{2}$, Cem Demirel ${ }^{1}$ \\ ${ }^{1}$ Department of Obstetrics and Gynecology, Acibadem University, Istanbul, Turkey \\ ${ }^{2}$ Department of Radiology, Acibadem Hospital, Istanbul, Turkey
}

\section{Abstract}

Transient osteoporosis of pregnancy is a rarely observed skeletal pathology developing in the last months of pregnancy. Meticulous evaluation is important for the differential diagnosis of severe and progressive hip and/or groin pain in pregnant patients. MRI is a valuable and safe technique for demonstrating bone marrow edema and skeletal abnormalities during pregnancy. Avoidance of vaginal delivery and non-weight bearing measures are essential in order to prevent complications such as hip fractures related to transient osteoporosis of pregnancy. We present the diagnostic evaluation and treatment of an uncommon case of transient osteoporosis of pregnancy with resolution of symptoms and postpartum.

(J Turkish-German Gynecol Assoc 2010; 11: 163-4)

Key words: Osteoporosis, pregnancy, hip pain

Received: 12 November, 2009

Accepted: 24 J anuary, 2010

\section{Özet}

Gebelikte geçici osteoporoz seyrek olarak gebeliğin son haftasında iskelet gelişim patolojilerine neden olur. Özenli tanı ve yaklaşım özellikle kalça ve omurga ağnsı çeken hastalarda önem kazanır. Vaginal doğumdan kaçınmak geçici osteoporoza bağlı kalça kınklannın önlenmesinde önem arzeder. Yazımızda böyle bir vaka bildirilmiştir.

(J Turkish-German Gynecol Assoc 2010; 11: 163-4)

Anahtar kelimeler: Osteoporoz, gebelik, kalça ağnsı

Geliş Tarihi: 12 Kasım 2009

Kabul Tarihi: 24 Ocak 2010

\section{Introduction}

Musculoskeletal symptoms such as hip, pelvis and groin pain are common complaints of pregnancy. They are associated with increased weight and position of gravid uterus which affects the axial skeleton and causes neural compression by fluid retention and hormonal changes leading to joint laxity (1). These symptoms are usually managed conservatively without specific diagnosis. However, there may be cases with severe and progressive, pain especially during the second and third trimester of pregnancy $(2,3)$. Transient osteoporosis of pregnancy (TOP) needs to be considered for differential diagnosis in these cases.

TOP during pregnancy was first reported by Curtis and Kincaid in 1959 (4). It is a rarely observed, self-limiting pathology of unclear etiology with severe onset of groin and/or hip pain progressive in character, mostly during the third trimester of pregnancy. The patient may not be able to walk or may present with an antalgic gait due to functional disability. The current case report presents an uncommon case of TOP during pregnancy and reviews the literature.

\section{Case Report}

A 34 year-old, nulliparous woman had severe pain of increasing intensity in the right leg at 30 weeks of gestation. The pain was aggravated by getting up, sitting down and standing up. Clinical examination revealed mild pain without restriction of motion in the lumbar area. Abduction and external rotation of her right hip were limited by severe pain and she had an antalgic gait. The right lower segment of the abdomen was very tender to palpation at examination. She did not have any motor or sensorial deficit according to the neurologic examination. Lumbar discopathy was ruled out as a cause of the pain. Laboratory tests for electrolytes, thyroid function, rheumatoid factor and antinuclear antibody were normal. Magnetic resonance imaging (MRI) scans of the hips revealed alterations at the right coccygeofemoral junction consistent with transient osteoporosis accompanied by stress fracture (Figure 1). J oint aspiration was performed due to increased synovial fluid in the hip junction. She received analgesic treatment with paracetamol and nonsteroid anti-inflammatory drugs during pregnancy. During the remainder of the 
pregnancy she was prescribed bed rest and avoided weight bearing. Cesarean section was recommended considering the risk of hip fracture during normal vaginal delivery. Calcitriol 0.5 mcg and calcium 1000 mg were prescribed soon after delivery. Whole body scintigraphy performed one month after delivery also demonstrated osteoporosis. Calcium $1000 \mathrm{mg}$, vitamin D3 $880 \mathrm{IU}$ and salmon calcitonin $200 \mathrm{IU} /$ day, switched to alendronate $70 \mathrm{mg} /$ week, were started for six months according to the scintigraphy findings. Her symptoms and MRI findings regressed 6 months following delivery (Figure 2).

\section{D iscussion}

Physiotherapy, rheumatology and orthopedic consultations are considered for persistent, moderate to severe hip, back and/or groin pain during pregnancy. Pubic symphysiolysis, avascular necrosis, ostemyelitis, neoplasm and TOP should be ruled out in the differential diagnosis. Plain radiographs of the limb may demonstrate severe osteopenia for advanced cases of TOP. MRI is a more sensitive, safe and effective imaging technique for detecting skeletal abnormalities including TOP and hip fractures during pregnancy (5). Diffuse bone marrow edema by MRI, normal levels of markers for inflammation, severe and persistent groin and/or hip pain during the last months of pregnancy are positive findings for TOP.

Prevention or permission for only limited weight bearing is essential in order to avoid complications in TOP. Atraumatic fractures may also be observed. Hip fracture is reported during labor, therefore cesarean section is preferred in cases with TOP (6). The palliative approach to TOP includes use of non-weight bearing measures such as bed rest, wheelchairs, crutches, analgesia and physiotherapy. Hips are usually remineralized within 6-14

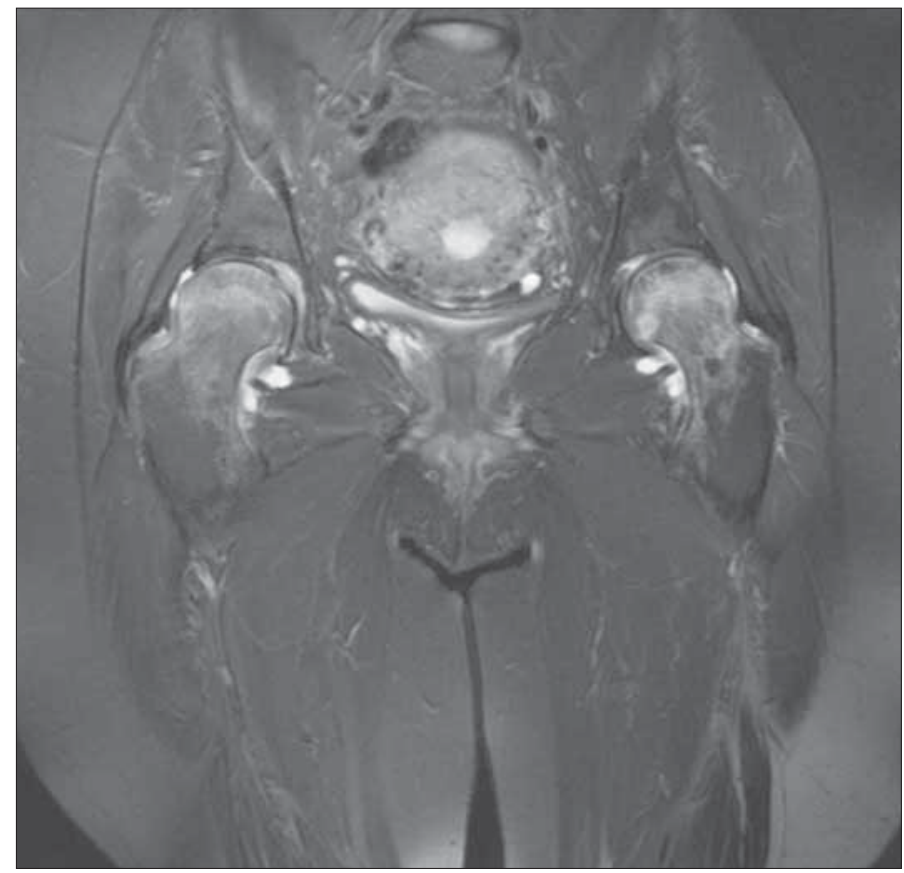

Figure 1. T2 weighted MRI demonstrates bone marrow edema in the femur head and neck and increased synovial fluid in the hip junction

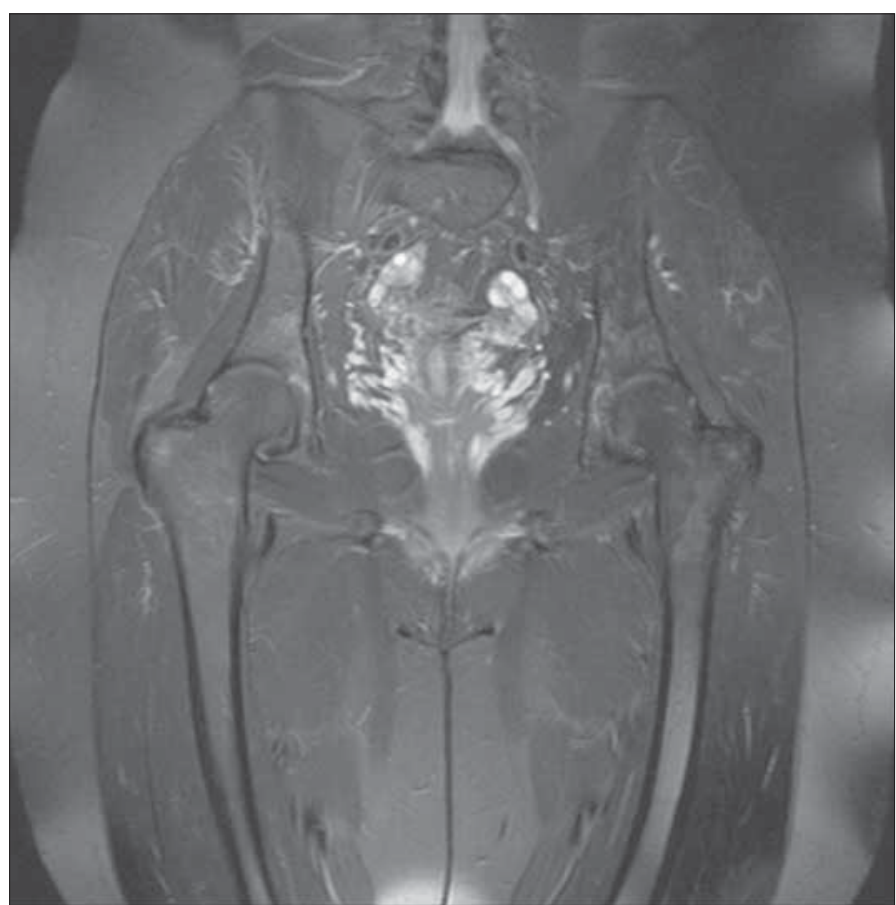

Figure 2. Fat suppressed T2 weighted sequences of the control MRI postpartum demonstrated normalization of bone marrow edema

months postpartum (7). Antiresorptive therapy with biphosphonates, calcium and vitamin $\mathrm{D}$ are used as adjunctive measures during the recovery period.

In summary, TOP should be considered for the differential diagnosis of severe hip pain during pregnancy. Early diagnosis and treatment are essential in order to prevent its complications.

\section{Conflict of interest}

No conflict of interest is declared by authors.

\section{R eferences}

1. Spinarelli A, Patella V, Speciale D, Petrera M, Vittore D, Pesce V, et al. Hip fracture in a patient affected by transient osteoporosis of the femoral head during the last trimester of pregnancy. Orthopedics. 2009; 32: 365.

2. Daniel RS, Farrar EK, Norton HR, Nussbaum Al. Bilateral transient osteoporosis of the talus in pregnancy. Osteoporos Int. 2009; 20: 1973-5.

3. Smith MW, Marcus PS, Wurt LD. Orthopedic issues in pregnancy. Obs Gynecol Surv 2008; 63: 103-11.

4. Curtis PH, Kincaid WE. Transitory demineralization of the hip in pregnancy: A report of three cases. J Bone J oint Surg Am 1959; 41: 1327-33.

5. Daniel WW, Sanders PC, Alarcon GS. The early diagnosis of transient osteoporosis by magnetic resonance imaging. J Bone Joint Surg Am 1992; 74: 1262-4.

6. Thomas E, Cox C, Murphy D, Beddard K. Hip fracture during labour due to transient osteoporosis of the hip in pregnancy. J Obstet Gynecol 2000; 20: 197-8.

7. Liel Y, Atar D, Ohana N. Pregnancy-associated osteoporosis: preliminary densitometric evidence of extremely rapid recovery of bone mineral density. South Med J 1998; 91: 33-5. 